\title{
Religion, 'Nature' and Environmental Ethics in Ancient India: Archaeologies of Human:Non- Human Suffering and Well-being in early Buddhist and Hindu contexts
}

\author{
Julia Shaw (UCL Institute of Archaeology)
}

\begin{abstract}
This paper assesses archaeology's contribution to debates regarding the ecological focus of early Buddhism and Hinduism and its relevance to global environmentalism. Evidence for long-term human:non-human entanglement, and the socioeconomically constructed element of 'nature' on which Indic culture supposedly rests, challenges post-colonial tropes of India's utopian, 'eco-friendly' past, whilst also highlighting the potency of individual human:non-human epistemologies for building historically grounded models of Indian environmentalism. For early Buddhism,I mediate between two polarized views: one promoting the idea of 'eco-dharma', as a reflection of Buddhism's alignment with non-violence (ahimsa), and the alleviation of suffering (dukkha); a second arguing that early Buddhist traditions have been misappropriated by western environmentalism. I argue that the latter view subscribes to canonical models of passive monks removed from worldly concerns, despite archaeological evidence for socially-engaged monastic landlordism from the late centuries BC. Others cite this evidence only to negate Buddhism's eco- credentials, thereby overlooking the human:non-human entanglement theme within modern environmental discourse, while the predominant focus on non-human suffering overlooks convergences between modern and ancient ecological ethics and environmental health. Case studies include examples of Buddhist land and water management in central India, set within discussions of human v. non-human-centric frameworks of well-being and suffering, purity and pollution, and broader Indic medico-ecological epistemologies, as possible models for collective responses to environmental stress.
\end{abstract}

Keywords: Archaeology as Environmental Humanities; Indian religion and 'nature'; Agriculture, food change and environmental control; Violence and non-violence; Purity and Pollution

\section{Introduction}

Within contemporary environmental discourse, ancient Indian traditions of religious-philosophical knowledge have been drawn upon as providing resources for global environmental ethics. Yet the question as to whether they support attitudes towards nature and its resources in 'eco-friendly' ways has been approached almost entirely from textual and anthropological perspectives, with archaeology playing a comparatively insignificant role. The aim of this paper is to introduce archaeological evidence into the debate, especially with regards violent v. 'non-violent' (ahimsic) attitudes towards animals, plants, foodproduction, land and water use, and to relate discussions of Indian religion and 'nature' to broader scholarship on Environmental Health and environmental activism on the one hand, and to help forge a closer alliance between archaeology and the Environmental Humanities on the other. It also introduces current and future themes of the Religion and Nature in Ancient India Project, which through collaborative research in Archaeology, Religious Studies and Indian Studies, assesses comparatively attitudes of early Buddhism, and religious traditions that are now called 'Hindu' and which draw on (either in continuum or transformation of) older Vedic-Brahmanical texts, towards land and water-use, and environmental control (Shaw et al. Forthcoming). The project addresses gaps in the understanding of the interface between religious, socio-economic and environmental change, perpetuated partly by a lack of coordinated interdisciplinary teamwork, and to help clarify to what extent ancient Indian religio-philosophical traditions upheld notions of 'nature', 'environment' and environmental ethics that can contribute to contemporary ecological discourse.

A key question is how both Buddhist and Hindu religious-philosophical traditions responded to new environmental challenges between the mid first millennium $B C$ to early centuries $A D$, in the face of reactions to established Vedic worldviews, rising urbanism, and changing socio-political structures. 
Buddhism and Hinduism are viewed alongside each other here, for whilst traditionally placed in 'heterodox' v. 'orthodox' camps, both emerge out of and respond to shared religious-philosophical histories. I examine Indic notions of 'nature' and 'culture', human and non-human well-being and suffering ( $d u k k h a)$, violence and non-violence (ahimsa), and purity and pollution, questioning how such notions, particularly with regards food, diet and the human body, correspond to the language of modern environmentalism. I also examine the relevance of 'devolved' examples of religious-based institutional management of land and water resources to scholarship and activism focussed on adaptive responses to present-day environmental and climate change, and its impact on human health, well-being and suffering. Focussing on early Buddhism, I steer a middle path between two polarised views, one having promoted Buddhism as 'ecodharma' (dharma has a wide range of religio-cultural meanings, but for the current purposes, refers specifically the teachings of the Buddha) on the basis of its preoccupation with non-violence (ahimsā), and the well-being and (alleviation of) suffering (dukkha) of non-humans; the second drawing on philosophicaltheological arguments aimed at discounting the environmentally-engaged model of Buddhism (Schmithausen 1997). My position is that the critics of eco-dharma subscribe largely to the canonical model of passive monks removed from worldly concerns, thus overlooking archaeological evidence for monasticism landlordism from the late centuries BC. Some (Elverskog 2014) have drawn on this evidence, only to further negate Buddhism's eco credentials. Such scholars tend to misconstrue modern environmentalism as a rejection of agriculture, rather than a quest for greater human:non-human equilibrium, and by focussing on the non-human dimension of suffering alone, overlook the meeting point between modern and ancient versions of environmental ethics.

The second, closely related question is the degree to which religious institutions acted as agents of knowledge viz. influencing archaeologically attested changes in land-use, food culture and land-tenure in early-historic India, as illustrated by the changing dynamics between irrigated rice, and non-irrigated wheat (and millet) crops, and the widespread adoption of vegetarianism, especially as urbanism and related phenomena spread westwards from the Gangetic valley. To date, Indian archaeobotany has focussed on Neolithic origins of domestication (Fuller 2005; Kingwell-Banham et al. 2015), with less emphasis on later periods, or on how religio-philosophical developments influenced, or responded to changes in food production and consumption; whilst an archaeology of food in specifically Buddhist contexts awaits further study (Coningham 2001, 88).

The main case-study is provided by my own work in central India, the Sanchi Survey Project (henceforth SSP), aimed at assessing the socio-ecological background of Buddhist propagation in the late centuries BC (Shaw 2007), with less detailed reference to comparative South Asian material. Based on the distribution of Buddhist monasteries, habitational settlements and water-resource systems around the early monastic site of Sanchi (Ibid.), I focus on early Buddhism's relationship with land and water-management, and new forms of food production as responses to social and environmental stress on the one hand, and as agents of new cultural attitudes towards food and the body on the other. I argue that the sarigha (monastic order)'s engagement with environmental control (a position which becomes reformulated in later years within competing Hindu contexts) was - like its later involvement with medicine (Zysk 1998) and banking (Schopen 1994) - both an instrument of lay patronage, and closely related to Buddhism's deeper preoccupation with human suffering (dukkha) and the means of its alleviation: one of the key messages that arose from the Buddha's Enlightenment was that we suffer if we do not live correctly (Schlieter 2014). This paper focuses on one particular aspect of this erroneous living and consequent suffering, viz. human modes of engagement with the physical world. Situated critically within broader discussions of 'monasteries as gardens' (Ali 2003; Schopen 2006; Shimada 2012), it assesses the gradual and long-term 
process of monumentalisation and entanglement with the socio-ecological environment that underpinned the development of sedentary monasticism in the Sanchi area.

\section{Archaeology, Religion and Environmental ethics}

A key argument here is that the debate about the prominence, or not, of environmental ethics in early Buddhism has been skewed by a one-sided interpretation of environmentalism as being concerned with 'nature' as an entity removed from humans, rather than with human:non-human entanglement. Thus, the relevance of the Buddhist doctrine of suffering (dukkha) to the environmental movement is seen as lying in its concern for animal welfare, over and above the recognition of the impact of environmental stress on human well-being and suffering. Similarly, both popular media-oriented environmental activism, as well as the burgeoning field of scholarship on the Anthropocene, and Environmental Humanities, focuses more on anthropogenic environmental stress and climate change, than on consequent human disease and suffering, stemming as much from individual contributory factors such as synthetic chemical use, as from the direct effects of climate change itself.

Whilst Rachel Carson's (1962) seminal work on the detrimental environmental and health impact of synthetic biocides adapted from their original function as chemical weapons for human-destruction, led to improved regulation of specific chemical groups, its message is as, if not more, relevant than when it was first published. Whilst the Mass Media discusses the 'probable' carcinogenic properties of isolated herbicides, the broader link between synthetic chemicals and human illness, well attested within Environmental Health circles (Samsel \& Seneff 2013; Downs 2015; 2016b), receives less emphasis. Similarly, regulations for pesticide spraying focus more on the protection of hedgerow species than of humans (Downs 2015), against the growing support for an environmental model of disease aetiology (Steingraber 1997; Giasson \& Lee 2000; Genuis 2012; Mostafalou \& Abdollahi 2013; Samsel \& Seneff 2013; Goodson et al. 2015; DellaValle 2016).

In this sense, broader recognition within the social sciences of human:non-human 'entanglement' (Appadurai 1986; Hodder 2012; Latour 2013) is not greatly removed from the language of Environmental Health, and particularly epigenetics, which demonstrates that whilst humans are changing their environment, this new synthetically altered environment is changing humans at an inter-generational level through genetic, epigenetic, and endocrinal disruption (Genuis 2012; Dupre \& Parry 2010; Dupre 2013; Mostafalou \& Abdollahi 2013; DellaVale 2016). Such developments within Environmental Health are helpful for further diffusing entrenched nature:culture and human:non-human polarities and challenging popular perspectives of the 'green movement' as being concerned 'only' with the 'environment' and thus being marginal to mainstream politics. One might argue that 'eco-friendly' policies would receive more public support if better linked to issues of human and economic well-being. And similarly, by taking a more human-centric approach to suffering and the means of its alleviation viz. early Buddhist engagement with land and water-management, one can better draw on commonalities between modern and ancient environmental ethics, thereby increasing possibilities for fostering positive environmental change.

The main requirement here is not only the modification of behaviour through the adoption of standard 'green policies' such as recycling or low-energy lighting, but the alteration of beliefs and attitudes about our place in a human:non-human world. Despite 1000 s of peer-reviewed publications on the increasingly wellestablished environmental paradigm of disease aetiology (Genuis 2012), or anthropogenic climate change, changing unsustainable individual habits of consumption is challenged by inconveniently high stakes, 
embedded in corporate profit from the agro-chemical industries, and the need for cheap mass-produced food (Downs 2016a), and new ideals of personal hygiene and domestic aesthetics regarding 'pests' and 'weeds' (Robbins 2007). Hence in the UK at least, environmental activism may be viewed as 'subversive civil disobedience' (Luke 1999), justifying intrusive and covert surveillance-based policing on the basis of its perceived threat to 'national economic security', as sanctioned by the Regulation of Investigatory Powers Act (RIPA) (Newlands 2013).

How are such attitudes to be changed? Who determines beliefs about climate, human well-being and the aetiology of disease? In modern nation-states, government legislation informed by scientific consensus, shapes public recognition of specific environmental hazards (Holm et al. 2015). Viewing religion as 'worldview' (Shaw 2013b), and in contexts such as ancient India where empirical knowledge is often modulated by religio-philosophical bodies, deeper probing of religious perceptions of purity/pollution, or harmful/non-harmful human:non-human relationships is crucial.

In recent years as major world religions have embraced the growing environmental crisis, each offering statements as to their position on 'sustainability' (Dorje 2006; Grim and Tucker 2014; Hulme 2016), Religion and Ecology has become a fast-developing subject area with several active research forums (e.g., http://fore.yale.edu/; http://www.hf.ntnu.no/relnateur/). By contrast, apart from several agenda-setting papers on heritage and landscape ethics (Dalglish 2012), environmental ethics, and particularly its relationship to religion, has received little attention in archaeology. A recent major volume on religion and ecology, for example (Tucker et a/ 2016) includes not a single archaeology-oriented contribution. Similarly, with very recent exceptions (Riede 2016), archaeology has a very scant presence within Environmental Humanities research forums, and has only recently began to respond to Earth Scientists' framing of the Anthropocene as a largely post-Industrial Revolution phenomenon(Crutzen \& Stoermer 2000), drawing on much earlier evidence for human:non-human entanglement, particularly agricultural domestication (Fuller 2007; Hodder 2012, 75-6), from the mid-Holocene transition c. 6000 BP (Edgeworth 2014; Lane 2015; Braje 2016; Dalby 2016, Randall 2016). Even deeper socio-ecological histories from c. 10,000 BP are suggested for South and East Asia and the Near East (Morrison 2015; Boivin et al. 2016), whilst evidence for the long-term history of forest exploitation is challenging modern environmentalist narratives of deforestation as a largely post-Industrial phenomenon (Morrison \& Lycett 2014; Clement et al. 2015; Evans In Press).

Further, pre-modern climate-based models of urban decline and 'collapse' include the posited weakening of the summer monsoon in 4.1 Ky BP / $2100 \mathrm{BC}$ and its supposed impact on the transformation of Harappan urbanism after c. 1900 BC (Dixit et al. 2014), particularly in relation to land-use and settlement distribution. However there has been little questioning of how these posited outcomes were digested by religiophilosophical traditions, especially those concerned with human health and well-being. Further, significant uncertainties remain regarding the ensuing period, from the composition of the $R g$ Veda, through to the reemergence of urbanism and complex political organisation in the Gangetic valley around 1000 years later, processes which form the backdrop to the early history of the religious traditions discussed here. Key explanations for this 'second urbanisation' include metallurgical innovation, with the iron plough and axe facilitating the expansion of intensive agriculture into previously inaccessible, forested, areas. This model has been challenged by improved survey methods, revised iron chronologies (Tewari 2003), and revisionist theories regarding the history of forest exploitation in South Asia (Morrison \& Lycett 2014). However, the 
precise relationship between urbanisation and environmental history, especially as urban-based polities spread westwards from the Gangetic valley from c. $3^{\text {rd }}$ century $B C$, is still an unsettled matter, as is the interface between environmental change, transformations of material culture, and religion-based intellectual and practical responses particularly with regards Orthodox and Heterodox challenges from the mid' first millennium BC, to older Vedic rituals and worldviews. Buddhism, for example, is viewed variously both as a catalyst and outcome of urbanism, as well as a reaction to the negative side-effects of urbanisation such as poverty, illness and pollution, offering a means for tackling consequent suffering (Bailey \& Mabbett 2003; Shaw 2013a, 88-90). Notwithstanding the dialectical and sometimes contradictory nature of these two positions, whereby Buddhism flourished partly because monks could mediate between different political and economic forces at times of turbulent social change (Shaw 2013a, 89), there are obvious parallels with the mixed outcomes of modern urban development.

\section{Archaeologies of Religion and 'Nature' in ancient India}

In response to the modern challenges of rapid urbanisation, industrialisation, and the fallout of the ironically-termed Green Revolution (Shiva 1992), contemporary environmental discourse has drawn on ancient Indian traditions of religious-philosophical knowledge as representing a pre-modern ecological utopia whose expectation of care for the environment contrasts with modern realities. This notion is reinforced by the rhetoric of post-colonial scholarship (Morrison \& Lycett 2014), and Hindu-nationalist party politics as expressed in the ruling BJP's $(2014,1)$ pre-election manifesto: '[Pre-colonial] India was a land of abundance, prosperity, affluence, ... of sharing and caring living in perfect harmony and peace with the nature' (also Simhastha 2016, points $14 \& 16$ ).

There are multiple, oft-cited explanations for such assumptions but only rarely do these acknowledge the socially constructed element of the sense of 'nature' on which Indic culture supposedly rests. 'India' and 'Hinduism', for example, derive etymologically from the river Indus, while the Ganges is envisaged as a goddess descending from the sacred Himalayas, the abode of Śiva, through the body of the earth goddess Prithvi. Many of India's individual sacred geographies are defined by entwined notions of topography and divine embodiment, the Śakti Pițha, for example being configured by the distribution of goddess body parts (Fleming 2009), while the Buddhist 'world map' takes the form of a giant Buddha corpse comprised of individual corporeal relics (Walters 2002). What is less discussed is the degree to which these early examples of religious mapping are bound up with competing frameworks of custodianship and control of land and its resources (Shaw 2015). Much of India's ritual landscape reflects a reverence for the inherent sacredness, or what Otto (1923) called the numen loci, of particular places, marked out by 'natural' shrines consisting of rock-shelters, or unhewn stones piled up beneath trees, both rocks and trees being objects of worship since ancient times (Kenoyer et al. 1983; Coningham et al. 2013). However, many such shrines are today less connected with abstract notions of 'nature' than with place-bound deities and tutelary spirits believed to continue to reside in ancient settlements long after their abandonment, thus also embodying notions of collective memory, whether 'invented' or matched by archaeological 'evidence', and entwined with monumentalised representations of the divine (Shaw 2000; 2007, 75-7; also Casile 2014). Closely related are swayambhu, 'self-manifest' images fashioned from 'natural' rocks, their particular sectarian identity mediated through dreams or visions, and playing an important role in land claims (Coccari 1989). The earliest anthropomorphic sculptures, datable to the late centuries BC, are of yakșa and nāga (serpent) deities, regarded as manifestations of dangerous natural forces, and propitiated in order to regulate rainfall, or ward off drought, floods and certain illnesses (Shaw 2004; 2007, 55-9; 2015; Sanderson 2011; Dandekar \& Dandekar 2011, 221-2). As discussed below, following a 'religion as technique' model (Peel 1968), the assimilation of these deities into Buddhism (and contemporary and later Hindu traditions) was 
an important means of legitimising Buddhism's claims as a (more) dependable means of environmental control through technological, and specifically, hydraulic knowledge (Shaw 2004; 2013a).

The deep history of reverence for trees, sacred forests and groves, has also provided fertile ground for Indo-centric conservation activist traditions such as the Chipko forest-protection movement (Bandopadhyay \& Shiva 1986). Morrison and Lycett (2014), however, highlight the social construction of Indian forests, whose long history of exploitation from at least the Neolithic challenges the popular trope of the timeless, primordial sacred forest disturbed only by colonial developers (Gadgil \& Guha 1992; Bhat et al. 2001), and presented as synonymous to 'nature', whilst 'human action, especially agriculture, plays the role of culture' (Morrison \& Lycett 2014, 150). Their argument that 'nature, or the environment, is always anthropogenic, and anthropogenesis is perpetual' (Ibid. 148-9), is supported by Cambodian (Evans In Press) and Amazonian (Clement et al 2015) evidence for large agro-urban settlement of areas previously assumed to be 'virgin' tropical forest.

The rejuvenation of ancient water-resource structures as sustainable alternatives to 'big dam', World-Bank development models, is another key theme in Indian conservation activism (Agarwal \& Narain 1997). The supposed 'benign' associations of the Hindu 'temple-tank' tradition, and earlier Buddhist counterparts discussed below, are presented as examples of 'devolved' water-management in contrast to Wittfogelian centralised models. However, as Morrison (2010) argues, many such dams, those in South India extending up to $3 \mathrm{~km}$ in length, may be regarded as 'Big Dams'. And despite holding sacred waters and being administered by religious organisations, one should not assume a disconnection from centralised authority, especially given the entwined relations between imperial rule and land-owning Hindu deities (Willis 2009). These gods residing in temples are still the biggest land-owning entities in India (Sontheimer 1964), a legal privilege invested through imperial powers from the Gupta period onwards (Willis 2009), arguably in direct competition to earlier Buddhist-based models of land and water management discussed below (Shaw 2007). As Morrison $(2010,192)$ states, Indian reservoirs 'were always politically and religiously charged features', bound up with motives of power and profit.

However, whilst the mixed outcomes for those living upstream or downstream means that dam-building is rarely without controversy, one should distinguish between socio-political and environmentalist grounds for opposition, and as discussed later, the main argument for the 'sustainability' of indigenous water-resource systems relates to the highly localised design of many pre-modern dam traditions (Sutcliffe et al. 2011), and codified rules governing reciprocal community access to irrigation supplies (Agarwal \& Narain 1997). Further, recognition of the social construction of nature should not discount the potency of individual ecological concepts within Indic religion, including epistemologies and definitions of body, e.g., Purușa/Prakrti (wherein Purușa is the Universal or individual soul and 'knower' of Prakrti, insentient or 'productive' matter (Malinar ref), consisting of kșetra, as both 'field' and 'body') (Malinar 1988, 1990, 2010a; Jacobsen 1999), which blur human:non-human boundaries and offer ways for challenging human:nature inequities, and Eurocentric frameworks of embodiment and associated legal jurisdiction based on the prioritisation of the human body (Büchler 2012). It is thus important to consider the longterm histories of human:non-human entanglement out of which individual socio-ecological and agrarianbased economic models emerge.

\section{Purity and Pollution: religious v. environmentalist categories of dirt?}

Central to scholarly understanding of food-production and the use of non-human resources in Buddhist and Hindu environments are Indic notions of purity and pollution. The prevalent assumption in anthropology and archaeology, following from Douglas (1966), is that Hindu concerns with purity and pollution are based solely on 'ritual' preoccupations, the precise definition of which is rarely made explicit. It is important to 
distinguish between polluting actions or substances which require ritual purification as prescribed in Sanskrit texts (Malinar 2000; 2010b), and actions bracketed off as 'ritual' in the broader anthropological sense of habitualised action. The ongoing tendency in the anthropological/archaeological literature (Morrison 2012, In Press) is to place 'purity', 'pollution' or 'contagion' in inverted commas, implying therefore notional rather than empirical categories of cleanliness, hygiene or dirt. There are frequent references to 'displaced' 'anxiety' of an assumed phobic or irrational nature (Morrison 2012, 338; In Press) about animal consumption and other contaminants including impure water, dead bodies, or low-caste professions such as leather tannery. Further, the anthropological take on 'ritual' purity and pollution viz. vegetarianism overlooks scholarship on meat-avoidance as a reflection of Indian religious-philosophical attitudes towards the human:non-human world (Malinar 1988, 1999, 2010a), as well as the impact of certain foodstuffs on the human body according to caste and constitution (Zimmermann 2004). It also reflects Eurocentric assumptions of meat-eating as a cultural norm, and overlooks the physical hazards of animal consumption, contact with dead bodies and other pollutants within a pre-refrigeration, pre-Germ Theory context, not to mention the hazardous nature of low-caste professions such as leather tannery, or human waste-disposal from a modern toxicological and environmental-health perspective.

The oft-cited illustration of the apparent contradiction between 'ritual' and 'real' notions of environmental pollution is the river Ganges (and the Yamuna) whose traditionally purifying waters are, within the language of Environmental Science, sources of hazardous industrial waste, untreated sewage, and decaying human corpses (Alley 2002; Haberman 2006). Hence, the revisionist picture of Hinduism as a distinctly anti-environmentalist tradition, which through a belief in the Ganges' inherent purifying qualities, is able to transcend (and ignore) the 'reality' of a worsening environmental crisis. However, notwithstanding the question of Hinduism's adaptive abilities, early medical texts suggest that some preindustrial categories of 'pure' / sacred places, land and water overlapped closely with medico-ecological categories, with certain places reputedly imparting healthy (or harmful) 'imprints' on the human body by virtue of their geological or botanical profile, or anthropogenic alteration (Zimmermann 1980, 105; 2004, $377-8 ; 1980,105)$. The link between climate, environment, illness and healing is expounded in the classical Ayurvedic texts, with humid, 'swampy' environments being associated with phlegm-related problems, remedied by meats and honey from 'dry lands' whose 'harsh and light qualities compensate for the excesses of the climate' (Zimmermann 1980, 105). We may query therefore how traditional definitions of sacred or pure space correspond to modern expectations of cleanliness or conservation, especially when associated practices and products are themselves connected with ill health from the modern perspective of environmental health. An example of such a conundrum (Shaw Forthcoming) is the use of synthetic biocides in the conservation of living temples under the custodianship of the Archaeological Survey of India (e.g., IAR 1997-8, 330-368). Deeper understanding of the interface between traditional Indic notions of human ecology and the language of environmental health and epigenetics calls for focussed collaboration between archaeologists and textualists, together with geoarchaeological and archaeobotanical assessment at key nodes of India's socio-ritual landscape (Shaw et al. Forthcoming).

\section{Ahimsā: the ethics of non-injury in Indic environmental discourse}

A second major theme in the Indian religion-and-ecology debate is the doctrine of non-injury or nonviolence (ahimsa), which developed during the mid' first millennium BC as part of an ascetical protest against the Vedic sacrificial tradition in which all living beings are regarded as food; the eater has absolute power over the eaten, with vegetables occupying the lowest rung on the food chain (Zimmermann 1992; Jacobsen 1994; Stewart 2014). The ascetical position that no living being should be the food for another arguably influenced the increased importance of plant-based food, and the widespread adoption of vegetarianism (Jacobsen 1994; Schmithausen 1997). And whilst increased ploughshare agriculture would 
have supported these developments, it was also rejected and viewed as injurious ( $h i m s i c$ ), by certain Brahmanical ascetic groups. This arguably created a polarisation between urban life based on irrigated crop agriculture, and ahimsic asceticism based on wild or unirrigated crops (Malamoud 1996; Olivelle 2006). The Brahmanical ascetic has thus been described as 'anti-civilizational', 'acting contrary to the norms of civilized behavior, [and] imitat[ing] animals, the inhabitants of the wild' (Olivelle 2006, 94; 95-6). Further, urban life, and in particular the consumption of domesticated cereals, is linked with new illnesses, and the consequent birth of Ayurvedic medicine (Zimmermann 2004, 274). Accordingly, the Brahmanical forest aśram, based around horticultural 'gardens' or groves is presented as the utopian 'synthesis' between the himsic urban, and the ahimsic 'wild' life of the forest (Malamoud 1996; Zimmermann 2004 for järigala as forest v. vana as grove/garden/managed woodland).

Although caution is needed regarding these hitherto archaeologically untested assumptions, especially given that the introduction of the metal ploughshare in the first millennium BC builds on several preceding millennia of domesticated crop agriculture (Kingwell-Banham et al. 2015), the textually attested link between non-agricultural land and ascetic, peripatetic lifeways is matched to some degree by the topographical setting of many early ritual centres, including the Buddhist monastic sites in central India discussed later (Shaw 2007, 142). Whilst it is important to distinguish between ascetic and mainstream attitudes towards agriculture, a rather ironic outcome is the development of urban and courtly garden traditions as media for the emerging urban elites' display of power and sophistication (Smith 1994), a development which has interesting repercussions within Buddhist monastic contexts, as discussed below. It is also important to acknowledge the apparent divergence between Brahmanical and Buddhist ascetic attitudes towards 'wild' v. domesticated forms of food production, and to question whether different ascetic groups influenced varying economic and agrarian outcomes through time and space.

\section{Buddhism and Ecological Ethics}

Staying with early Buddhism, the debate regarding Buddhist attitudes towards 'nature' (Strain 2016) falls into two main camps, with the so-called 'eco-apologists' (Swearer 2006) promoting Buddhism as a kind of 'eco-dharma' (Oliver 2004; Dorje 2006; Harvey 2007), and the 'eco-critics' alleging misconstrual of the Buddha's original teachings (Schmithausen 1997; Harris 1997; Swearer 2006). The eco-dharma argument draws largely on early Buddhism's commitment to non-violence (ahimsa) and the alleviation of suffering (dukkha), and to later Mahayana traditions, of the Buddha of Compassion and the expectation of care towards the natural world. The assumption is that Buddhists

'would not thoughtlessly saw down a tree or pull up plants ... would be equally thoughtful ... to animals, and would ... not ... use resources from the natural world without careful thought..... The Buddhist attitude would preclude excessive mining for minerals, the destruction of forests for building purposes, or the pollution of rivers with industrial waste'(Oliver 2004, 176; cit. Elverskog 2014, 968-9).

The doctrine of the Origination in Dependence, the idea of interdependence in the human- non-human world, and a major influence behind Arne Næss' (2003, 271) 'deep ecology' (Strain 2016, 197), is also central to Buddhism's ecologically aware reputation:

'If we accept that we are not isolated individuals but instead one whole made up of all life on Earth, we cannot remain indifferent to the suffering and ills that occur here. With this understanding, generating compassion for all living beings and turning that motivation into action is the most ecologically aware thing we can do' (Dorje 2006, 1095). 
The critics of the 'eco-dharma' model, however, argue that this reputation reflects a misrepresentation of the early Canonical tradition (Schmithausen 1997; Swearer 2006), and misappropriation by Western environmentalism (Harris 1997: 388, 395; also Strain 2016). Schmithausen (1997) questions both the prominence of an ecological ethics within the Pâli Canon, and the relevance of Buddhist teachings on the environment to contemporary ecological concerns. He also challenges the adequacy of the doctrine of Origination in Dependence with its emphasis on rebirth, as a basis for the eco-dharma model, arguing that it is only in later Buddhism (especially in Chinese Hua-yen tradition) that the link with the principle of universal interdependence and interrelatedness became formalised. He also stresses the lowly status of animals, deemed as objects of contempt in early Buddhist texts, arguing that far from being actively concerned with the environment, early Buddhists followed a form of 'passive environmentalism', impressed not so much by the beauty of nature as by its negative aspects: it sought not to transform or subjugate nature but to transcend it spiritually through detachment.

A similarly 'passive' stance is highlighted in Buddhist attitudes towards vegetarianism and diet in general. Although compassion (karuna) towards animals, and retribution for animal-killing, in this and the next life, together with the doctrine of transmigration, are recurring themes in early Buddhist texts (Stewart 2014), the Buddha permitted monks 'to eat meat and fish provided that they do not see, hear, or suspect that the animal was killed specifically for their own consumption' (Mcdermott 1989, 274; Ruegg 1980, 234-5; for vegetarianism in Mahāyāna Buddhism, Ibid; Stewart 2014). The concern is purportedly thus with morality rather than with the physical or energetic results of what enters one's body as food, or the suffering of the consumed animals: 'The Buddha held that one does not become pure as a result of the food [one] eats, but rather as a result of practicing self-restraint' (Mcdermott op.cit; Ruegg 1980, 235). This assumed 'passive environmental action', which may not always have been in the best interests of the eater - as illustrated by the Buddha's final meal that reputedly killed him (Wasson 1982) - contradicts the Brahmanical tridoșa-based framework which associates certain diets with different body types determined by caste (Smith 1990), with specific foodstuffs and modes of preparation/cooking, being sources of dangerous pollution. This assumed passivity may be viewed as a kind of 'opting out' from ethical debates: with several exceptions (Ruegg 1980 for 'forbidden meats'), monks are supposed to eat whatever is put in their begging bowl, and are thus absolved from the effects of food-related decisions with regards purity and pollution (Shaw et al. Forthcoming).

\section{Monasteries as Gardens: transcendence or control of nature?}

A similar level of detachment is highlighted in the recent monasteries-as-gardens debate (Ali 2003; Schopen 2006; Shimada 2012): abundant plant imagery in sculpted Buddhist reliefs of the late centuries BC at Sanchi and Bharhut, for example, is seen not as an indicator of real plants and 'nature', but rather an idealised utopia, or 'dharma' space (Brown 2009). Schopen (2006) argues that the spatial relationship between monasteries and urban centres mirrored the removed distance between pleasure groves and courtly centres. Direct donations of such groves and gardens to the sarigha for conversion into monastic complexes (e.g., Prince Jeta's donation to Sravasti monastery), are known from the canonical texts (Shimada 2012, 2), which also prescribe the ideal spatial relationship between urban centres and monasteries as:

....'neither too far from a village, nor too near, suitable for coming and going, accessible to people whenever they want, not crowded by day, having little noise at night, little sound, without folks' breath, secluded from people, fitting for meditation....'(Vinaya Pitaka II, 158) 
This ideal fits with broader debates regarding the dialectic relationship between urban courtly culture and Buddhist asceticism, with Ali (2003) viewing the monastery as an ascetic inversion of the urban and courtly ideals of the Kāma Sütra. The monastic garden symbolises the sarigha's attempt to situate itself within an increasing urban culture based on the ideal of worldly pleasure (kāma), the acquisition of wealth (artha), and the performance of social duty (dharma), polar opposites of the monk's dharma which involves the transcendence of kāma in order to reach liberation (mokșa). The garden provides the setting for stories of courtly love and romantic dalliance, a world which the Buddhist monk must strive to transcend. Similarly, whilst sculptural depictions at Buddhist sites of semi-clad women in suggestive poses are usually viewed as yakśiss, spirits of nature, and particularly, trees, Shimada (2012) sees them rather as courtesans, wellknown from the Buddhacarita as protagonists in romantic, garden-based stories: just as plant imagery reminded lay visitors of urban gardens, these figures were symbols not of 'fertility cults' but of courtly luxury and sophistication, and ultimately, the worldly pleasure (kāma) which the Buddha and Boddhisattvas had renounced.

Again, we return to the theme of transcendence of, rather than engagement with 'nature'. But, we should not regard gardens, least of all courtly gardens, as 'natural' places but rather epitomes of control and artifice (Ali 2003, 223). And whilst Schopen (2006, 498-505) draws on textual and archaeological accounts of beautiful 'views' of the bucolic countryside afforded from such places, suggesting that monastic gardens were places from which to view 'nature' from a safe distance, in the Sanchi area at least, archaeological settlement and land-use data discussed below, suggest that monks would have looked out onto a highly cultivated, 'managed' agrarian and hydraulic landscape, dotted with semi-urban habitational sites (Shaw 2007; 2015). Further, the control and harnessing of 'nature' is what the Buddhist monastery excelled at, particularly when it came to water, and the garden illustrated this ability with the maximum visual impact (Ibid. Shaw 2004). Examples include the ostentatious display of water-storage facilities at rock-cut complexes in the Deccan, and irrigation water-resources within broader monastic-centred archaeological complexes in Sri Lanka, central India and further afield. Rather than representing symbols of transcendence of the 'natural' world, I argue that these features acted as instruments of lay patronage, as outward symbols of the sarigha's ability to 'tame' and harness natural resources, and specifically to harvest and store water in regions of climatic uncertainty (Shaw 2004, 2007, 2013a). Whilst local populations were previously dependent on rain-making cults for timely rainfall and the moderation of drought and floods, mediated through the propitiation of dangerous serpent deities (Ibid., Cohen 1998; for parallels in eighthcentury Tibet, Dalton 2004; Cantwell \& Mayer 2013), they now had access to reliable and timely water supplies due to technological and administrative know-how. Without water people suffer, especially in regions where $90 \%$ of annual rainfall occurs in two-to-three months, and the sarigha's ability to alleviate this suffering was made explicit through outward symbols of its engagement with environmental control.

This angle can be extended to the aforementioned sculpted plant imagery and 'nature spirits', as symbols of the sarigha's ability to 'live well' with 'nature', harness its resources, and overcome its more dangerous and unpredictable elements. The majority of $2^{\text {nd }}$-century-BC sculpted plant imagery at Sanchi represents aquatic species such as lotus, sometimes accompanied by fish, and other aquatic creatures such as turtles and snakes. I contend that this imagery reflects the 'watery' landscape in which the monastic complex is set, as represented by recently documented reservoirs below Sanchi hill (Shaw \& Sutcliffe 2001, 2003, 2005; Shaw et al. 2007). This hydraulic landscape forms the basis of an emerging 'Buddhist economics' which sustains monks as a non-producing section of society, and provides a practical means for alleviating human suffering. The aquatic vegetation depicted in early Buddhist relief-sculpture accords with an irrigated rice-growing environment which had long since formed the backdrop for the earliest Buddhist communities in the Gangetic valley, and which as argued below, would have accompanied Buddhism as it 
spread westwards. By virtue of this hydraulically engineered landscape, Sanchi too would have been surrounded by rice paddies and associated swampy vegetation as depicted in early Buddhist art, and also reflected in preliminary pollen sequences from excavated reservoir deposits (Shaw et al. 2007). Similarly, yakśas, yakśiss and nāgas were not necessarily 'local' nature spirits but rather formed part of a ritualecological package which mirrored older realities in the Gangetic valley heartland (Cohen 1998; Shaw 2004). Symbolically too, Sanchi hill and related sites can be viewed as rising from primordial waters in ways that mirror cosmogonic references to Mount Meru at many sacred sites in South and South-east Asia. As argued later, the earliest monasteries here were established only after long periods of pre-monumental engagement with comparatively untamed, peripheral zones of the settled landscape. Such imagery can thus be viewed as mnemonic indicators of monks' transformation, rather than transcendence, of nature on the one hand, and their transcendence of conventional modes of urban-based production and consumption on the other.

This discussion is relevant to debates regarding Buddhism's 'middle-way' approach to asceticism and agrourban culture which contrasts with the alleged 'anti-civilizational' stance of its Hindu ascetic counterparts (Olivelle 2006). Benavides $(2005,82)$ argues that Buddhism was neither a rejection nor affirmation of urban society, but rather a 'commentary' on new attitudes to labour, consumption and wealth. It also implied new attitudes towards purity and pollution: whilst monks cannot partake in labour, the lay donations (dāna) on which they depend is generated by the polluting work of others. Through a reworking of Brahmanical purification rituals, the donor is thus cleansed of the polluting effects of his/her actions through the ritualised exchange of gifts and religious merit (punya).

These gift-giving rituals were central to the development of institutionalised monasticism (Schopen 1994; Shaw 2013a): whilst the Buddha and his earliest followers found support from the merchant and royal classes of Magadha, Buddhism's spread beyond the Gangetic valley was linked to the patronage of the Mauryan Emperor Asoka ( $3^{\text {rd }}$ century BC). However, it is not until the post-Mauryan period (second - first centuries BC) that Buddhism really takes root in the landscape, in a grandiose and radical process of monumentalisation, fuelled almost completely by collective patronage (Shaw 2013a), or what may be regarded as an early form of 'crowdfunding' (Shaw Forthcoming), with individual architectural components displaying the inscribed names of their respective donors. Epigraphs recording land, village and labour grants appear in the early to mid' first millennium AD, and Schopen (1994) argues that the adoption of sedentary monasticism did not occur until this late period despite older scholarship on material and textual evidence for monastic landlordism from the second century BC in Sri Lanka (Gunawardana 1971), as corroborated by more recent archaeological research discussed later in both Sri Lanka (Coningham et al. 2007; Coningham \& Gunawardana 2013; Gilliland et al. 2013) and central India (Shaw \& Sutcliffe 2001, 2003, 2005). Similar evidence in Southeast Asia is central to discussions of 'Buddhist economics' (Green 1992; Harvey 2000: 215-9; Pryor 1990), which like Islamic variants, differs from either capitalist or socialist ideologies, and has undergone a recent religio-political renaissance, with proponents (Schumacher 1973, 48) highlighting the socio-environmental impact of business transactions, and alternative currencies to monetary profit, such as happiness and well-being.

The fact that the archaeological evidence for monastic-landordism has not been incorporated into the 'Buddhist environmentalism' debate is an obvious lacuna which this paper seeks to address. A rare exception is Elverskog (2014) who ironically draws on this material to contest the eco-dharma argument, following a similar reasoning as those who have critiqued the post-colonial trope of the pre-modern, temple-governed reservoir as an unequivocal alternative to 'Big-Dam' development models (Morrison 
2010). Elverskog's (2014) stance, however, betrays a vision of environmentalism as a rejection of landexploitation rather than a quest for sustainable human:non-human relationships. Further, it reflects a similarly Eurocentric vision (ironically promoted also within post-colonial scholarship) of Indian natureconservationist models as highlighted by Morrison \& Lycett $(2014,150)$ for South India where the failure to acknowledge the social construction of forests from the Neolithic, has shaped the prevalent view that the 'solution' to forest 'degradation' is a reversion to total wilderness, in contrast to the mainstream conservationist model of forest 'management' in Europe. Similarly Elverskog (2014) argues that early Buddhism could not have supported an 'eco-friendly' attitude towards nature due to its vested interests in land and water-management. This view may also reflect the enduring influence of a canonical vision of Buddhism which presents forest monasticism, divorced from the forces of production, as the 'original' and higher ascetic path in relation to urban monasticism (Gombrich 1988). But moreover it fails to recognise the sarigha's engagement with environmental control as a reflection of its concerns with human suffering, its causes, and means of its alleviation. The eco-dharma debate focuses largely on the issue of suffering (dukkha), and by extension, non-injury of non-humans rather than humans. E.g., discussions of agricultural insect-control in Buddhist contexts (Smith 1990), overlook the environmental and human-health consequences of pesticide-use beyond a 'concern for insects'. And whilst the eco-critics may argue for a certain detachment from insect-sufferance, the recognition of an offender, rather than victim-centred ethics in Buddhist attitudes to suffering, whereby the perpetrator of violence suffers more than the victim (Schlieter 2014), is important here especially when insect-killing impacts negatively on human health (Carson 1962). My argument is that forming as it does the central tenet of early Buddhist thought, the alleviation of human suffering, together with the need for patronage, should be at the forefront of our understanding of Buddhist forms of environmental control.

\section{The Sanchi Survey Project: long-term patterns in the socio-ecological landscape}

The Sanchi Survey Project (SSP) in central India was initiated in 1998 with the aim of relating the westward spread of Buddhism and other religious traditions from the Gangetic valley during the late centuries BC to socio-economic and ecological history including urbanisation, state-formation and new forms of land-use, food production and environmental control. Several phases of survey and excavation have been completed (Shaw 2004, 2007; 2009; 2011; 2013a; 2013c; 2015; Shaw \& Sutcliffe 2001; 2003; 2005; Shaw et al. 2007; Sutcliffe et al. 2011), with subsequent phases under development (Shaw et al. Forthcoming). The study covers approximately $750 \mathrm{~km}^{2}$ around the UNESCO World Heritage, Buddhist site of Sanchi, and the ancient city of Vidisha several kilometres to the north. Earlier seasons resulted in the documentation of ritual sites, habitational settlements, sculptural and architectural material, rock-shelters, water-resource structures, land-use data, and various other 'non'-sites, with individual sites forming interrelated archaeological clusters or 'complexes' (Shaw \& Sutcliffe 2001; Shaw 2007; Shaw 2013c). The 'early-historic complex' at Sanchi, for example, provides a microcosmic model for the identification of patterns within the wider, interconnected socio-ecological / ritual landscape (Shaw 2007, 70-1).

The majority of monastic sites occupy hilltops, whose visual prominence affords certain practical, strategic, ritual and symbolic benefits (Shaw 2007, 2009, 2015). The spatial relationship between monasteries and settlements, rarely more than 1-2 km apart, conforms to aforementioned canonical rules regarding proximity, and yet distance, between monastery and village / town, mirroring the monastery's dialectical relationship to society, being detached on the one hand but financially dependent on lay patronage on the other (Gombrich 1988, 95, 156). Sanchi's earliest constructional history is connected with royal Mauryan patronage, and subsequently, collective, largely non-royal patronage, during the post-Mauryan period (Shaw 2007; 2011). For daily nutritional needs monks would have relied on the support of local 
communities, initially through begging rounds, and eventually, as monastic communities grew, through more integrated patronage systems based on an agricultural surplus, rather than subsistence-based economy (Bailey \& Mabbett 2003, 70-2; Shaw 2013a, 103).

By the post-Mauryan period, the size and scale of Buddhist monasteries (Shaw 2011) and the relative configuration of settlements and dams is sufficiently similar to those underlying Sri Lankan monastic landlordism (Gunawardana 1971), to warrant the assumption of a similar three-way exchange system between land-owners, monasteries and the agricultural laity (Shaw \& Sutcliffe 2001; 2003). The Sri Lankan textual and epigraphical evidence suggests that this system was mediated through the monastic administration of land and water-resources, whilst local communities handled the physical running of the dams and the irrigation facilities that they provided, performing a similar function as the 'service villages' (aramikagāma) described in early Buddhist texts (Culavamisa v. 46.115). More recent survey and excavation work in Sri Lanka has supported the idea of a 'theocratic' hydraulic landscape in Anuradhapura's hinterland (Coningham et al. 2009; Coningham \& Gunawardana 2013), with comparative studies in eastern India (Sen 2014, 67), Bihar (Rajani 2016, 6), and the Northwest (Olivieri et al. 2006, 131-3). Similar relationships are inferred for Thotlakonda in Andhra Pradesh, where ceramic assemblages attest to on-site food preparation and storage by non-monastic staff, rather than to food collection through individual mendicancy (Fogelin 2006, 152-3, 165).

A number of supporting propositions have been offered regarding the temporal and spatial dynamics of Sanchi's socio-ecological landscape based on the SSP landscape data (Shaw 2007; 2013c). First, Chalcolithic settlement distribution and ceramic evidence attests to limited sedentary occupation within the low-lying areas from at least the second millennium BC although settlement density increases massively towards the middle-to-late centuries BC (Shaw 2015, 394-5.). Clearly, the incoming sanigha did not choose completely unsettled areas, and further, the establishment of large monumental monastic complexes was a gradual process. Secondly, the distribution of painted rock-shelters and prehistoric tools attests to peripatetic, possibly hunter-gatherer occupation in the hilly zones from at least the Chalcolithic period. Given the later associations of such non-agricultural zones with property-renouncing ascetic groups, it is possible that as a non-producing entity, the incoming sarigha was limited in its choice of places to settle (Ibid.). Many prehistoric rock-shelters surviving around the edges of these complexes were adapted for monastic use, possibly representing an intermediate stage between peripatetic and sedentary monasticism as represented by post-Mauryan monasteries; similar 'monastic shelters' are widely known in central India, notably Pānigurāriyā (Falk 2006; IAR 1975-6, 28-30; Shaw 2007, 117, pl. 52) and Bhimbetka (Shaw 2007, $37)$ in Hoshangabad and Raisen districts respectively, and closely related to the $3^{\text {rd }}$-century-BC drip-ledged shelters (lena) of Sri Lanka (Coningham 1995). Some shelters were undoubtedly occupied into later periods as part of a two-tiered urban/forest model of monasticism as evidenced in Sri Lanka and Southeast Asia (Ibid.). Future excavation of the SSP shelters, together with rock-art analysis, is expected to clarify their chronological and historical relationship to structural monasteries and institutional monasticism, whilst palynological and geoarchaeological analyses will enable testing of hypotheses regarding the relationship between Buddhist propagation, forest clearance and land-tenure (Shaw et al. Forthcoming), and by extension, the sarigha's alleged pioneering role in encouraging population shifts into new areas (Ray 1994, 5). This is particularly important given that the latter model has been presented as an early analogy for medieval examples of Hindu and Islamic 'monastic governmentality', as agents for 'render[ing] difficult spaces habitable.... [and] sacraliz[ing] such lands and forests, whether on top of a mountain, or on the plains' (Chatterjee 2015), as well as shedding light on early Buddhist interactions with communities beyond the urban sphere. 
Many of the aforementioned shelters contain older, Chalcolithic, paintings of wild animals depicted in hunting, or post-butchery scenes, with skins hanging in lines, or animals shown with their internal organs and skeletal structure visible (Neumayer 2011). Contemporary pottery from the area bears similar themes. This rich and only partially documented repertoire, albeit the focus of a growing body of 'rock-art studies', has yet to be incorporated into debates regarding Buddhist attitudes to 'nature', as well as the history of anatomical knowledge (Shaw Forthcoming). The latter has hitherto focussed largely on knowledge drawn from the Vedic sacrificial tradition, later codified in classical Ayurvedic medical texts, and arguably modulated partly through Buddhism which unlike orthodox Brahmanism was not restricted by prohibitions over contact with polluting bodily substances (Zysk 1986; 1998). The human knowledge of, and interaction with, animals and animal anatomy outwith the Sanskrit textual tradition, does not figure in this debate; an obvious shortcoming which needs to be addressed through collaborative textual and archaeological research. Buddhist forest monks would have had as close dealings with the hunting communities that created this art as they did with local farmers, and indeed, as today, there would have been considerable overlap between these two lifeways. When these monastic 'locales' do become monumentalised, the element of fortification is prominent, with key structures raised on high platforms and surrounded by high boundary walls (Shaw 2000, 2007, 110-145). These features would have provided security against potential hostile human action, but also wild animals, a frequent motif in early Buddhist sculpted relief alongside the aforementioned plant imagery, possibly as reminders of the more dangerous aspects of nature with which monks were closely familiar. Tigers, bears and leopards are still every-day hazards in many parts of central India, and the older, peripatetic monsoon retreat-based tradition, out of which sedentary monasticism grew, would have given monks very direct exposure to nature in its most verdant, unpredictable and often dangerous forms, in ways which presented real threats to human wellbeing and longevity. Notable here is a chapter in the Sutta Pițaka of the Pāli Canon (Majjhima Nikaya v. 4) entitled 'Bhaya-bherava Sutta' ('Discourse on Fear and Dread'), which expounds the Buddha's teachings to jungle-dwelling ascetics on meditation practices aimed at overcoming the fear of wild animals (Nānamoli and Bodhi 1995, 102-107; for Brahmanical parallels see Olivelle 2006; for contemporary Thai forest monasticism, see Tiyavanich 1997, 79-105; and Indian 'tiger charming' traditions, see Jalais 2010).

\section{Reservoirs, rice-production and monastic landlordism}

Finally, the central basis of our working hypotheses regarding monastic landlordism in central India is provided by a group of 17 stone-faced, earthen dams, distributed across the SSP study area in close proximity to monastic sites (Shaw \& Sutcliffe 2001, 2003, 2005; Shaw et al. 2007; Sutcliffe et al. 2011). Surviving up to heights of $6 \mathrm{~m}$, and lengths of $1400 \mathrm{~m}$, they supported reservoirs with areas up to $3 \mathrm{~km}^{2}$, and volumes up to 3 million cubic metres. Some such as the main Sanchi dam were built on gradually sloping terrain, providing inundation reservoirs for upstream irrigation, others extended across deeper valleys for downstream irrigation, and some had spillways and sluice gates. Based on contextual material and OSL / TL dating of dam and reservoir sediments (Shaw et al. 2007), the earliest construction phase was dated to $c .3^{\text {rd }}-2^{\text {nd }}$ centuries BC, in keeping with the Mauryan and post-Mauryan phases at Sanchi and neighbouring Buddhist sites.

Analyses of surface remains and local present-day hydrology enabled further hypotheses regarding reservoir design, function and associated land-use. Individual reservoir storage capacity of up to 3 million cubic metres far exceeds the needs of modern agriculture which until the introduction of tube-well irrigation in the 1990s, was based on rain-fed wheat cultivation (Shaw \& Sutcliffe 2001; 2003a; 2005). The near absence of irrigation relates to local, high moisture-retaining black-cotton soils which store sufficient water from monsoon recharge to support winter wheat crops from planting to maturity. Low population density following several recorded waves of famine-related emigration since the $14^{\text {th }}$ century, is another 
factor, and after the 1899-1900 drought (Imp. Gaz, vol. ix, 374-5), it was suggested that any major population resurgence would likely necessitate agricultural reintensification, including the adoption of irrigation (Watt 1889, vol. 6, 151). This raises obvious questions regarding land-use during the late centuries BC when site distribution in Vidisha' hinterland attests to considerably higher settlement density than today, with 29 out of 133 settlements occupying levels two to four of a six-tiered hierarchy (Shaw 2007, 226; cf. however Hawkes 2014 who misconstrues the SPP data as implying a prevalence of 'urbanmonasteries' in the area), and with large monasteries, now abandoned, spread over every hilltop. Whilst the aforementioned drought-related emigration influenced low irrigation use in recent times, the earlier disappearance of Buddhism, from around the $10^{\text {th }}$ century, was probably more significant. Some waterbodies were evidently used in later periods for bathing and domestic supplies, but the decline of Buddhism was a key catalyst for their ceasing to function as irrigation resources. The abandonment of monasteries would have led to serious economic downturn, lowering food production requirements, and rendering the upkeep and repair of the reservoirs unviable. Similar explanations (Lucero et al. 2015, 1148), together with climate fluctuation (Ibid., Gilliand et al. 2013, 1026-7), are suggested for the disuse of reservoirs in DryZone Sri Lanka, with further analogies in South India where Chola and Pallava dam inscriptions recorded terms and conditions for reservoir administration and desiltation. Once these sources of patronage dried up, so did the reservoirs (Davison-Jenkins 1997, 93; Venkayya 1906). That the Sanchi dams were already out of action by the earliest recorded drought and consequent depopulation of the $14^{\text {th }}$ century -and possibly even earlier given recent evidence for rainfall variation of the monsoon during the early second millennium AD (Jung et al. 2004; Gunnell et al. 2007) - is supported by 19th century famine records which demonstrate that those areas with continued use of traditional irrigation systems were better immune to the effects of severe drought (Agarwal \& Narain 1997, 182-3).

Whilst recognising the probability of higher irrigation requirements in the past, we have argued that the Sanchi dams were not designed for wheat cultivation, but rather for newly introduced rice, the staple of the Gangetic valley since at least the $2^{\text {nd }}$ millennium BC, and whose westward and southward spread, according to hitherto untested hypotheses, did not occur until early-historical periods (Fuller 2005). Although today, supplementary tube-well irrigation of say $50 \mathrm{~mm}$ can be generated without canal transfer, extensive canalisation is necessary to distribute reservoir water over large areas; larger growing areas are needed for wheat than for rice which requires concentrated areas with minimum irrigation depths of about $800 \mathrm{~mm}$ (Shaw 2007 250). The high cost of dam construction and maintenance are justified for rice cultivation, largely because of the dramatically increased depth and intensity of irrigation but also because of the high water-storage capacity of local soils. By contrast, the construction of dams and canals is a less cost-effective way of increasing wheat yields than bringing new land into cultivation, especially when the availability of cultivable land was not a limiting factor in the area.

Based on historical water-balance records a total reservoir storage capacity of $19.5 \mathrm{~m}^{3} \times 10^{6}$, and irrigation capacity of $24 \mathrm{~km}^{2}$, have been estimated across the study area (Shaw \& Sutcliffe 2001; 2005). This illustrates the intensive nature of rice irrigation, requiring significant water storage to supply relatively small but highly productive growing areas to meet high food needs. An estimated average annual rice crop of approximately $2400-3600$ t/year, is significantly higher than for wheat. For example, late- $19^{\text {th }}$ century records show that the annual yield for unirrigated wheat across the whole Central Provinces was just 90 to $135 \mathrm{~kg} / \mathrm{ha}$ (Watt 1889-93, iv, 153). Whilst this comparison is an over-simplification, it demonstrates the impact of introduced irrigated rice on food-production as a response to rising urban and non-producing populations (Lucero et al 2015, 1143-6, for similar links in Dry-Zone Sri Lanka), our suggestion being that it formed part of a cultural package that accompanied the spread of new religio-cultural traditions from the Gangetic valley. 
Our account of locally cultivated rice should be viewed against the highly seasonal nature of local cultivation and climate, with over $90 \%$ of total rainfall (annual average $1300 \mathrm{~mm}$ ) occurring between June and September. This pronounced seasonality was a key factor behind the development of irrigation technologies in ancient India, with water storage facilities providing both monsoon flood-control, and insurance against drought (Sutcliffe et al. 2011); it also led to the prevalence, across much of monsoondependent India, of a double-cropping cycle, with the planting of rice in summer, and wheat in winter (Ibid.). We have argued, however, that local conditions made central India better suited to a complementary cropping system, with the Sanchi reservoirs providing intensive irrigation for rice cultivation, whilst supplementing rain-fed cultivation of both summer kharif and winter rabi crops in surrounding areas. This contrasts to the double-cropping cycle suggested for medieval reservoirs of the western Deccan (Morrison 1995a, 212), as well as the traditional ahar dams of southern Bihar which provide downstream irrigation of summer kharif rice crops, and upstream irrigation of winter rabi crops (wheat, barley and sometimes rice) within the reservoir beds themselves (Agarwal \& Narain 1997, 86-98; Sutcliffe et al. 2011, 281-2). Designed in response to local sandy soil-conditions which cannot support an unirrigated winter crop, the ahar design would make little sense for central India's clay-rich, moistureretaining soils.

Indeed, the highly localised nature of water-resource technology is a key factor in the success of many premodern irrigation traditions (Sutcliffe et al. 2011), and their appeal as indigenous alternatives to modern 'Big-Dam' developments. Whilst several areas of influence have been considered for Sanchi's dam-based irrigation technology, we have discounted either a ready-made, or trial-by-error, model. Rather, the relationship between reservoir volume, local catchments and runoff volumes suggests that they were built by a professional engineering class following a considerable period of observation of local conditions. We have suggested a gradual unfolding of intensive forms of land-use as monasteries became larger and more integrated in the local economy. Evidence for a palaeotank incorporated into the design of an early-historic reservoir (Shaw 2007, 253, n. 45; Shaw et al. 2007) supports suggestions that the earliest dams were of a makeshift, temporary nature, only later developed in durable materials in response to changing socioeconomic conditions (Shaw \& Sutcliffe 2003a, 80-1; Agarwal \& Narain 1997, 166-75). This mirrors the similarly suggested trajectory from adapted rock-shelter dwellings to permanent, structural monasteries, in keeping with the development from peripatetic to sedentary monasticism. As such locales became more monumentalised, so did the relationship of 'entanglement' (Hodder 2012) between monks and their socioecological landscape become more entrenched.

Given the lack of a recorded history of commercial rice-production in the area, our suggestion of largescale rice-cultivation in central India will undergo testing through geoarchaeological and archaeobotanical analyses, together with text-based analysis of the changing cultural and religious significance of irrigated rice versus unirrigated wheat or millet (Shaw et al. Forthcoming). The archaeobotany of Indian rice has hitherto focussed on Neolithic origins of domestication in the Gangetic valley (Fuller 2005; KingwellBanham et al. 2015). For later periods we are dependent on textual references to paddy fields and rice cultivation, either as backdrops to Buddhist narratives or metaphors for Buddhist discipline (Benavides 2005, 80; for 'field' ( kșetra) as metaphor for the human body, and the planting, cultivation and harvest of acts (karma) in Hindu Sāmkhya philosophy, see Malinar 2016; for a similar analogy between healthy soils and healthy bodies in Ayurvedic medical texts, see Zimmermann 2004, 377-379), which suggest that the landscape in which the 'second urbanisation' and the first Buddhist communities grew up was an overwhelmingly rice-growing one. Although archaeological samples from central India are lacking, evidence from the Deccan and South India suggests that the introduction of rice to these areas accompanied the 
spread of urban-based polities during the late centuries BC (Fuller 2005; Shaw 2013a, 99). The comparatively superior yields and nutritional value of rice in relation to native millets made it an effective solution to growing urban and monastic populations, its centrality to theories linking population stress and 'agricultural involution' being well-known from Southeast Asia (Geertz 1963), but its introduction to central India, first as a traded ingredient, and later as a cultivated crop, may also be viewed as a natural outcome of spreading populations and new religio-cultural traditions rooted in the rice-growing Gangetic valley (for east Asian and Mediterranean parallels, Fuller \& Rowlands 2005; Sherratt 1999).

Morrison (2016) suggests that in medieval South India, irrigated rice, as the preferred grain of the urban elite, formed part of a two-tiered food hierarchy, with unirrigated millet remaining the staple of the masses. Morrison touches upon the possible cultural, religious and health variables in this binary set-up, particularly the high ritual status of rice in Brahmanical contexts. However, there were evidently highly divergent attitudes, both within and between religious communities and castes, towards different grains and their physical and 'energetic' impact on the body, and the precise classifications and taxonomies that regulate the production and consumption of different foodstuffs in different religious contexts (ritual, ascetic, devotional) awaits focussed, interdisciplinary study (Shaw et al. Forthcoming). One must distinguish between minor ritual use of rice in Brahmanical temple worship, or donation to the Buddhist sarigha, and its broader religio-cultural associations influenced by caste, sect and locality; or between ascetic and mainstream interpretations. There are additional disparities between the perceived ritual and health properties of rice: despite its much heralded 'auspiciousness' in Brahmanical temple ritual (Morrison 2016), rice and cultivated cereals in general were arguably rejected by Brahmanical ascetics due to perceived links with violence (himsa) and ill health (Zimmermann 2004, 274). This reflects the often contradictory relationship between medical and ritual dispensations of purity, with the rules of Ayurveda ('the science of longevity') often overriding those given in religious texts, as without health one cannot pursue ones' goals; ritual, social or otherwise (Wujastyk 2004, 836-7). This last point is a crucial reminder of the need to keep human-centric preoccupations at the forefront of our understanding of Indic attitudes towards ecology, especially given the emerging 'environmental paradigm' within contemporary allopathic medicine, which in contrast to germ-based models of illness, stresses the importance of epigenetics, toxicology and nutrition as key aetiological factors in the emergence of disease (Genuis 2012).

\section{Conclusion}

A key question not yet addressed in archaeological assessments of food change in pre-modern India (Morrison 2016; Kingwell-Banham et al. 2015), is the influence of Buddhism on the presumed polarisation between rice and other cereal staples. The likely answer from the Canonical textual perspective is that monks must eat whatever they receive on their begging rounds and thus have little say in dietary matters. This idea follows the 'passive' model of Buddhism based on the ideal of peripatetic mendicancy geared towards individual enlightenment, and a literal reading of textual prohibitions (Anguttara Nikaya V, 17) against direct monastic ownership or management of agricultural land. However, scholarship on ritual giftgiving demonstrates that the success of monastic-lay exchange networks depended on the sarigha's ability to disguise its direct reciprocity, with lay managerial staff dealing with transactions and activities formally prohibited to monks. Here, Schmithausen's (1997) aforementioned designation of 'passive environmental activism' seems rather apt; not because of the sarigha's 'transcendence' of nature as Schmithausen maintained, but because it had to disguise its direct engagement with, and transformation of, natural resources in order to generate patronage necessary for sustaining a non-producing monastic population, and to tackle human suffering in wider society. Thus, while the SSP data supports an 'active' model of religious change (Shaw 2013a), the sarigha's involvement with land-use only works because of its 
perceived passivity, with monks seeming to be beyond nature and society. As demonstrated by historical examples of non-violent resistance as forms of civil disobedience, outward passivity matters less than the achievement of the intended aim..

The SSP data accord with 'religion as technique' models (Peel 1968), whereby monks moved into new areas with a set of motives for local communities to extend their economic support to the monastery. Medical analogies are also relevant, with the Four Noble Truths and Eightfold path aimed at the alleviation of suffering having close parallels with medical epistemologies (Schlieter 2014), but also because just as no single drug can treat all illnesses, the sanigha responded to individual social problems through the provision of certain practical services such as water, medicine (Zysk 1998) and banking facilities (Schopen 1994), without demanding religious conversion of local populations (Shaw 2013a). Offering as it does a humanfocussed model of well-being and suffering, it helps to diffuse the polarised rhetoric of the debate between the 'eco-apologists' and their critics with its narrow focus on the question of whether or not Buddhists were particularly concerned with the suffering of animals or with the 'beauty' of 'nature', a motif which also figures independently in the 'monasteries-as-gardens' debate. And by extension, far from negating the ecodharma model (Elverskog 2014), the history and chronology of monastic landlordism and the archaeological evidence for the gradual monumentalisation of Buddhist locales in the landscape, supports the idea of entanglement (Hodder 2012, 67) between monks and their physical and built environment through 'long-term relationships of material investment, care and maintenance' (Hodder 2012, 67), without which leads to decay and disrepair.

And whilst accepting the sarigha's pivotal role in agrarian and economic change which benefited local farmers and donors and increased well-being on a number of levels as well as enabling the sarigha to outwardly leave society, this is not to suggest that only Buddhism was experimenting with new forms of environmental control. Within the SSP area, the archaeological visibility of non-Buddhist strands of the religious landscape is confined to material connected with the proto-Vaiṣnava Pāñcarātra tradition or of otherwise ambiguous sectarian affiliation (Shaw 2004; 2007, 53-5; 176-193; 2013c) until the mid' first millennium $A D$, when we find a massive rise in Hindu (and Jain) temple construction, and a corresponding decrease in Buddhist building projects (Shaw \& Sutcliffe 2003, 78-9; Shaw 2007, 183-93; 2015; also Skilling 2014). Buddhist forms of land and water-management become appropriated and transformed by competing Brahmanical institutions, specifically the Hindu temple, which acquired legal powers to own and manage land and water resources (Willis 2009; Lacey 2014; Casile 2014), and developed rituals aimed at improving agriculture, including the prediction of the start and finish of the monsoon (Willis 2009). This was enabled not only through royal land-grants to Brahmins but by the new idea that images installed within temples are full embodiments ( $m u \bar{r} t$ ) of gods who can interact directly with devotees through worship ( $p \bar{u} j \bar{a})$ and who have full-blown legal jurisdiction to own property (Willis 2009, 122-7), in ways that parallel the dynamics of the earlier Buddhist monastic tradition, and associated stūpa and relic cult (Shaw 2015). Whilst the question as to whether ancient Indian religions supported attitudes towards nature and its resources in ways which can be described as 'eco-friendly' requires further interdisciplinary research (Shaw et al. Forthcoming), archaeological correlates for a socially and environmentally-engaged -'Buddhist economics' (Harvey 2000), together with the ahimsic aśram tradition, and later forms of Hindu 'monastic governmentality' (Chatterjee 2015), may be instructive for the modern ecological movement in offering 'non-violent' examples of collective, ideology-based, models of land ownership and management whereby 'states within states' act as alternative agents of socio-environmental change, in contrast to the monetary outlook of modern development-based governmental agendas. 


\section{Acknowledgements}

Much of the research for this paper was completed during a British Academy Mid-Career Fellowship (201415), with earlier fieldwork funded by the British Academy, Society for South Asian Studies, and Merton College, Oxford, under sanction of the Archaeological Survey of India, and Department of Archaeology, Museums and Archives, Madhya Pradesh. Grateful thanks to Paul Lane who assumed editorial responsibilities for this paper, and to Ian Hodder, Angelika Malinar, Jens Schlieter, John Shaw and two anonymous reviewers who made helpful suggestions for improving earlier drafts. All extant errors are my own doing.

\section{Notes on Contributor}

Julia Shaw is a Lecturer in South Asian Archaeology at UCL Institute of Archaeology and has been carrying out fieldwork in India for the last twenty years. Current research interests include South Asian environmental and socio-religious history; religion, medical knowledge and attitudes towards food and the body; global ecological discourse, environmental health, and Archaeology as Environmental Humanities.

\section{Bibliography}

Agarwal, A., and S. Narain. 1997. Dying Wisdom: Rise, Fall and Potential of India's Traditional Water Harvesting Systems. New Delhi: Centre of Science and Environment.

Alley, K.D. 2002. On the Banks of the Ganigã: When Wastewater Meets a Sacred River. Michigan: University of Michigan Press.

Ali, G. 2003. "Gardens in Early Indian Court Life." Studies in History 19(2): 221-52.

Appadurai, A. Ed. 1986. The Social Life of Things: Commodities in Cultural Perspective. Cambridge: Cambridge University Press.

Bailey, G., and I. Mabbett. 2003. The Sociology of Early Buddhism. Cambridge: Cambridge University Press. Bandopadhyay, J., and V. Shiva, 1986. Chipko: India's Civilisational Response to the Forest Crisis. New Delhi: Indian National Trust for Art and Cultural Heritage.

Benavides, G. 2005. "Economy." In Critical Terms for the Study of Buddhism, edited by D.S. Lopez Jr., 77102. Chicago; London: University of Chicago Press.

Bhat, D.M., K.S. Murali, and N.H. Ravindranath, 2001. "Formation and Recovery of Secondary Forests in India: A Particular Reference to Western Ghats in South India." Journal of Tropical Forest Science 13(4): 601-620.

BJP, 2014. Ek Bharat Shreshtha Bharat, Bharatiya Janata Party Election Manifesto 2014 (English). 7 April 2014. http://www.bjp.org/manifesto2014 (accessed 9/4/14).

Boivin, N. L., M.A. Zeder, D.Q. Fuller, A. Crowther, G. Larson, J.M. Erlandson, T. Denham \& M.D. Petraglia, 2016. "Ecological Consequences of Human Niche Construction: Examining Long term Anthropogenic Shaping of Global Species Distributions." Proceedings of the National Academy of Sciences 113: 6388-96.

Braje, T.J. 2016. "Evaluating the Anthropocene: Is There Something Useful about a Geological Epoch of Humans?" Antiquity 90: 504-512.

Brown, R.L. 2009, "Nature as Utopian Space on the Early Stūpas of India." In Buddhist Stūpas in South Asia: Recent Archaeological, Art-historical and Historical Perspectives, edited by J. Hawkes and A. Shimada, 63-80. New Delhi: Oxford University Press.

Büchler, A. 2012. "Regulating the Sacred. Organ Donation an Transplantation: Autonomy and Integrity of the Person or Social Responsibility of the Body". The Joseph and Gwendolyn Straus Institute of the 
Advanced Study of Law and Justice. Working Paper 01/12 www.law.nyu.edu/sites/default/files/siwp/WP1Buchler.pdf

Cantwell, C., and Mayer, R. 2013. "Representations Of Padmasambhava In Early Post-Imperial Tibet." In Tibet after Empire: Culture, Society and Religion between 850-1000, edited by C. Cüppers, R. Mayer, and M. Walter, 19-50. Lumbini: Lumbini International Research Institute.

Carson, R. 1962. Silent Spring. Boston: Houghton Mifflin.

Casile, A. 2014. "Changing Religious Landscapes in Gupta Times: Archaeological Evidence from the Area of Baḍoh-Pațhāri in Central India." South Asian Studies 30(2): 245-268.

Chatterjee, I. 2015. "Monastic 'Governmentality': Revisiting 'Community' and 'Communalism' in South Asia." History Compass 13/10: 497-511.

Clement C.R., W.M. Denevan, M.J. Heckenberger, A.B. Junqueira, E.G. Neves, W.G. Teixeira, and W.I Woods, 2015. "The Domestication of Amazonia before European conquest." Proceedings of the Royal Society, Biological Sciences 282: 20150813. http://dx.doi.org/10.1098/rspb.2015.0813

Coccari, D.M. 1989. "Protection and Identity: Banaras' Bir Babas." In Culture and Power in Banaras: Community, Power and Environment 1800-1980, edited by S.B. Freitag, 130-146. Berkeley; London: University of California Press.

Cohen, R.S. 1998. "Naga, Yaksini, Buddha: Local Deities and Local Buddhism at Ajanta." History of Religions, 37(4): 360-40.

Coningham, R.A.E. 2001. "Archaeology of Buddhism." In Archaeology and World Religion, edited by T. Insoll, 61-95. London: Routledge.

Coningham, R.A.E. 1995. "Monks, Caves and Kings: A Reassessment of the Nature of Early Buddhism in Sri Lanka." World Archaeology 27: 222-42.

Coningham, R.A.E. and P. Gunawardhana, 2013. Anuradhapura: Volume 3 The Hinterland. BAR International Series.

Coningham, R.A.E., P. Gunawardhana, M. Manuel, G. Adikari, M. Katugampola, R. Young, A. Schmidt, K. Krishnan, I. Simpson, G. McDonnella, and C. Batt, 2007. "The State of Theocracy: Defining an Early Medieval Hinterland in Sri Lanka." Antiquity 81 (313): 699-719.

Coningham, R. A. E., K.P. Acharya, K.M. Strickland, D.E. Davis, M.J Manuel, I.A. Simpson, K. Gilliland, J. Tremblay, T.C. Kinnaird, D.C.W. Sanderson, 2013. "The Earliest Buddhist Shrine: Excavating the Birthplace of the Buddha, Lumbini (Nepal)." Antiquity 87 (338): 1104-1123.

Crutzen, P. and E. Stoermer, 2000. "The 'Anthropocene'." Global Change Newsletter 41:17-18.

Dalby, S. 2016. "Re-evaluating the Anthropocene." Antiquity 90: 514-515.

Dalglish, D. 2012. "Archaeology and Landscape Ethics." World Archaeology 44:3: 327-341.

Dalton, J. 2004. "The Early Development of the Padmasambhava Legend in Tibet: A Study of IOL Tib J 644 and Pelliot tibétain 307." Journal of the American Oriental Society 124 (4): 759-72.

Dandekar, D., and A. Dandekar, 2011. "The Satvai and Settlement Pattern in Rural Western Maharashtra." South Asian Studies 27(2): 221-224.

Davison-Jenkins, D. J. 1997. The Irrigation and Water Supply Systems of Vijayanagara. Vijayanagara Research Project Monograph Series 5. New Delhi: Manohar

DellaValle, C. 2016. "The Pollution in People: Cancer-causing Chemicals in Americans' Bodies." Environmental Working Group Original Research. http://www.ewg.org/cancer/the-pollution-in-people.php Dixit, Y., D.A. David, A. Hodell, and C. A. Petrie, 2014. "Abrupt Weakening of the Summer Monsoon in Northwest India 4100 yr ago." Geology 42: 339-342.

Dorje, O. T. (H.H. 17th Gyalwang Karmapa), 2006. "Walking the Path of Environmental Buddhism through Compassion and Emptiness." Conservation Biology 25(6): 1094-1097.

Douglas, M. 1966. Purity and Danger: An Analysis of the Concepts of Pollution and Taboo. London: Routledge and Kegan Paul. 
Downs, G. 2016a. "From Hillsborough to Pesticides: Establishment Cover-ups, Lies and Corruption." Resurgence and Ecologist, 4th May 2016.

http://www.theecologist.org/News/news_analysis/2987648/from_hillsborough_to_pesticides_establishme nt coverups lies and corruption.html

Downs, G. 2016b. "No, the UN has not Given Glyphosate a 'clean bill of health'." Resurgence and Ecologist, 17 May 2016.

http://www.theecologist.org/News/news analysis/2987690/no the un has not given glyphosate a cle an_bill_of_health.html

Downs, G. 2015. "It's not just Glyphosate and Neonicotinoids! Why we Need a Pesticide-free Future." Resurgence and Ecologist, 30 April 2015.

http://www.theecologist.org/News/news analysis/2848400/its not just glyphosate and neonicotinoids why we need a pesticidefree future.html

Dupre, J. 2013. "A Postgenomic Perspective on Sex and Gender." Lecture at University of Cambridge, Diane Middlebrook and Carl Djerassi Visiting Professorship Lectures, 24 October 2013.

http://upload.sms.cam.ac.uk/media/1596279 (Accessed 15 Jan 2015).

Dupre, J., and S. Parry, 2010. Nature After the Genome, London: Blackwell Publishers.

Edgeworth, M. 2014. "Introduction, Archaeology of the Anthropocene, Forum discussion." Journal of Contemporary Archaeology 1(1): 73-77.

Elverskog, J. 2014. "(Asian Studies + Anthropocene)4." The Journal of Asian Studies 73(4): 963 - 974.

Evans, D. In Press (2016). "Airborne Laser Scanning as a Method for Exploring Long-term Socio-ecological Dynamics in Cambodia." Journal of Archaeological Science. http://dx.doi.org/10.1016/j.jas.2016.05.009 (accessed June 2016).

Falk, H. 2006. Aśokan Sites and Artefacts: A Source-Book with Bibliography. Mainz: Monographien zur indischen Archäologie, Kunst und Philologie, Band 18.

Fleming, B. 2009. "Mapping Sacred Geography in Medieval India: the Case of the Twelve Jyotirlingas." International Journal of Hindu Studies 13(1): 51-81.

Fogelin, L. 2006. Archaeology of Early Buddhism. New York: Altamira Press.

Fuller, D.Q. 2005. "Ceramics, Seeds and Culinary Change in Prehistoric India." Antiquity 79 (306): 761-777.

Fuller, D.Q. 2007. "Contrasting Patterns in Crop Domestication and Domestication Rates: Recent

Archaeobotanical Insights from the Old World." Annals of Botany 100: 903-24.

Fuller, D.Q. and M. Rowlands, 2011. "Ingestion and Food Technologies: Maintaining Differences over the Long-term in West, South and East Asia." In Interweaving Worlds: Systemic Interactions in Eurasia, 7th to the 1st Millennia BC, edited by T.C. Wilkinson, S. Sherratt, and J. Bennet, 37-60. Oxford: Oxbow.

Gadgil, M., and R. Guha, 1992. This Fissured Land: An Ecological History of India. Berkeley: University of California Press.

Geertz, C. 1963. Agricultural Involution: The Process of Ecological Change in Indonesia. Berkeley: Association of Asian Studies, University of California Press.

Genuis, S.J. 2012. "What's Out There Making Us Sick?" Journal of Environmental and Public Health 2012, Article ID 605137, 10 pages. doi:10.1155/2012/605137

Giasson, B. I., and V. M. Y. Lee, 2000. "A New Link between Pesticides and Parkinson's Disease." Nature Neuroscience 3(12): 1227-1228.

Gilliland, K., I.A. Simpson, W.P. Adderley, C.I. Burbidge, A.J. Cresswell, D.C.W. Sanderson, R.A.E. Coningham, M.J. Manuel, K.M. Strickland, P. Gunawardhana, and G. Akikari, 2013. "The Dry Tank: Development and Disuse of Water management Infrastructure in the Anuradhapura Hinterland, Sri Lanka." Journal of Archaeological Sciences 40: 1012-1028.

Goodson, W.H. et al. 2015. "Assessing the Carcinogenic Potential of Low Dose Exposures to Chemical Mixtures in the Environment: the Challenge Ahead." Carcinogenesis, 36 Suppl 1: S254-96. 
Gombrich, R. 1988. Theravada Buddhism: A Social History From Ancient Benares to Modern Colombo.

London: Routledge and Kegan Paul.

Green, R. M. 1992. "Buddhist Economic Ethics: A Theoretical Approach." In Ethics, Wealth and Salvation: $A$ Study in Buddhist Social Ethics, edited by R. F. Sizemore and D. K. Swearer, 215-234. Columbia:

University of South Carolina Press.

Grim, J., and M.E. Tucker, 2014. Ecology and Religion. Washington: Island Press.

Gunawardana, R.A.L.H. 1971. "Irrigation and Hydraulic Society in Early Medieval Ceylon." Past and Present 53: 3-27.

Gunnell, Y., K. Anupama, and B. Sultan. 2007. "Response of the South Indian Runoff Harvesting Civilization to Northeast Monsoon Rainfall Variability During the Last 2000 Years: Instrumental Records and Indirect Evidence." The Holocene 17: 207-215.

Haberman, D.L. 2006. River of Love in the Age of Pollution: The Yamuna River of Northern India. Berkeley: University of California Press.

Harris, Ian. 1997. "Buddhism and the Discourse of Environmental Concern." In Buddhism and Ecology: The Interconnection of Dharma and Deeds, edited by M.E. Tucker and D.R. Williams, 377-402. Cambridge, MA: Harvard University.

Harvey, P. 2000. An Introduction to Buddhist Ethics. Cambridge: Cambridge University Press.

Harvey, P. 2007. "Avoiding Unintended Harm to the Environment and the Buddhist Ethic of Intention." Journal of Buddhist Ethics 14: 1-34.

Hawkes, J. 2014. "One Size Does Not Fit All: Landscapes of Religious Change in Vindhya Pradesh." South Asian Studies 30(1): 1-15.

Hodder, I. 2012. Entangled: An Archaeology of the Relationships Between Humans and Things. Chichester: Wiley-Blackwell.

Holm, P., et al. 2015. "Humanities for the Environment - A Manifesto for Research and Action." Humanities 4: 977-992.

Hulme, M. 2016. "Varieties of Religious Engagement with Climate Change." In Routledge Handbook of Religion and Ecology, edited by M.E. Tucker, W. Jenkins, and J. Grim, 239-248. London, New York: Routledge.

Jacobsen, K. A. 1994. "The Institutionalization of the Ethics of 'Non-injury Towards All Beings' in Ancient India." Environmental Ethics 16(3): 287-301.

Jacobsen, K.A. 1999. Prakı̣ti in sāṃkhya-Yoga: Material Principle, Religious Experience, Ethical Implications. New York: Peter Lang.

Jalais, A. 2010. Forest of Tigers: People, Politics and Environment in the Sundarbans. London, New York: Routledge.

Jung, S. J. A., G. R. Davies, G. M. Ganssen, and D. Kroon, 2004. "Synchronous Holocene Sea Surface Temperature and Rainfall Variations in the Asian Monsoon System." Quaternary Science Reviews 23: 2207-2218.

Kenoyer, J.M., J.D. Clark, J.N. Pal, and G.R. Sharma. 1983. "An Upper Palaeolithic Shrine in India?" Antiquity 57: 88-94.

Kingwell-Banham, E., C. Petrie, and D. Fuller, 2015. "Early Agriculture in South Asia." In The Cambridge World History, edited by G. Barker and C. Goucher, 261-288. Cambridge: Cambridge University Press.

Lacey, H. 2014. "Nandivardhana and Nagardhan: Preliminary Analysis of the Surface Evidence from Nagardhan and Hamlapuri in the Eastern Vākāțaka Territory near Rāmțek, Maharashtra." South Asian Studies 30(2): 116-132.

Lane, P.L. 2015, "Archaeology in the Age of the Anthropocene: A critical Assessment of its Scope and Societal Contributions." Journal of Field Archaeology 40(5): 485-498. 
Latour, B. 2013. "Facing Gaia: A New Enquiry into Natural Religion." Series of Gifford Lectures, Edinburgh. http://www.bruno-latour.fr/node/486

Lucero, L.J., R. Fletcher and R. Coningham, 2015. "From 'Collapse' to Urban Diaspora: The Transformation of Low-density, Dispersed Agrarian Urbanism." Antiquity, 89, 1139-1154

Luke, T. 1999. "Environmentality as Green Governmentality." In Discourses of the Environment, edited by E. Darier, 121-151. Oxford: Blackwell.

Mcdermott, J.P. 1989. "Animals and Humans in Early Buddhism." Indo-Iranian Journal 32: 269-280.

Malamoud. C. 1996. "Paths of the Knife: Carving up the Victim in Vedic Sacrifice." In Cooking the World:

Ritual and Thought in Ancient India (trans. David White), edited by C. Malamoud, 169-80. Delhi: Oxford University Press.

Malinar, A. 2010a. "Purușa." In Brill's Encyclopedia of Hinduism, Vol. II: Sacred Texts and Languages,

Ritual Traditions, Arts, Concepts, edited by K. A. Jacobsen, H. Basu, A. Malinar, and V. Narayanan, 838843. Leiden: Brill.

Malinar, A. 2010b. "Purity and Impurity." In Brill's Encyclopedia of Hinduism, Vol. II: Sacred Texts and Languages, Ritual Traditions, Arts, Concepts, edited by K. A. Jacobsen, H. Basu, A. Malinar, and V. Narayanan, 435-449. Leiden: Brill.

Malinar, A. 2014. "Sensory Perception and Notions of the Senses in Sāṃkhya Philosophy." In Exploring the Senses: Asian and European Perspectives on Ritual and Performativity, edited by A. Michaels and C. Wulf, 34-51. London: Routledge.

Malinar, A. 2016. "Notions of 'Productive Matter' and the Classification of Beings in Indian Philosophy." Paper delivered at conference, Human: Non-Human:Bodies, Things, and Matter across Asia and Europe, URPP Asia and Europe, University of Zurich, October 6-8.

Morrison, K. 1995. "Trade, Urbanism, and Agricultural Expansion: Buddhist Monastic Institutions and the State in Early Historic Western Deccan." World Archaeology 27 (2): 203-221.

Morrison, K. D. 2016. "From Millets to Rice (and back again?): Cuisine, Cultivation, and Health in Southern India." In A Companion to South Asia in the Past, edited by G.R. Schug and S. Walimbe, 358-373. New York: Wiley Blackwell.

Morrison, K. D. In Press. "Water in South India and Sri Lanka: Agriculture, Irrigation, Politics, and Purity." In History of Water and Civilization, Volume VII, Water and Humanity: an Historical Overview, edited by Y. Yasuda and V. Scarborough. New York: UNESCO.

Morrison, K. D. 2010. "Dharmic Projects, Imperial Reservoirs, and New Temples of India: An Historical Perspective on Dams in India." Conservation and Society 8(3), 182-195.

Morrison, K. D. 2012. "Great Transformations: On the Archaeology of Cooking." In The Menial Art of Cooking, edited by S.R. Graff and E. Rodriguez-Allegria, 231-244. Denver: University Press of Colorado. Morrison, K. D. 2015. "Provincializing the Anthropocene." Seminar, 2015: Nature in History. Web edition. http://www.india-seminar.com/semframe.html

Morrison, K. D. and M. T. Lycett, 2014. "Constructing Nature: Socio-natural Histories of an Indian Forest." In The Social Lives of Forests: Past, Present, and Future of Woodland Expansion, edited by K. D.

Morrison, S. B. Hecht, and C. Padoch, 148-160. Chicago: University of Chicago Press.

Mostafalou, S., and M. Abdollahi, 2013. "Pesticides and Human Chronic Diseases: Evidences, Mechanisms, and Perspectives." Toxicology and Applied Pharmacology 268(2): 157-177.

Næss, A. 2003, "The Deep Ecology Movement: Some Philosophical Aspects." In Environmental Ethics: An Anthology, edited by A. Light, and H. Rolston III, 262-274. Malden, MA: Blackwell.

Nānamoli, B., and B. Bodhi, 1995. The Middle Length Discourses of the Buddha: A Translation of the Majjhima Nikāya. Somerville, MA: Wisdom Publications.

Newlands, M. 2013. Environmental Activism, Environmental Politics, and Representation: The Framing of the British Environmental Activist Movement. PhD thesis, University of East London. 
Neumayer, E. 2011. Prehistoric Rock Art of India. New Delhi: Oxford University Press.

Oliver, P. 2004, "Buddhism." In Encyclopedia of World Environmental History, vol. 1 edited by ,.S. Krech III, J. R. McNeill, and C. Merchant.6-173, New York: Routledge.

Olivelle, P. 2006. "The Beast and the Ascetic: The Wild in the Indian Religious Imagination." In Ascetics and Brahmins: Studies in Ideologies and Institutions, edited by P. Olivelle, 91-100. Florence: University of Florence Press.

Olivieri, L.M., M. Vidale et al. 2006. "Archaeology and Settlement History in a Test Area of the Swat Valley: Preliminary Report on the AMSV Project (1st Phase)." East and West 56 (1-3): 73-150.

Otto, R. 1923. The Idea of the Holy: An Inquiry into the Non-rational Factor in the Idea of the Divine and its Relation to the Rational. New York: Oxford University Press (trans. J.W. Harvey).

Peel, J.D.Y. 1968. "Syncretism and Religious Change." Comparative Studies in Society and History 10: 12141.

Pryor, F.L. 1990. "A Buddhist Economic System - In Principle." American Journal of Economics and Sociology 49(3): 339-350.

Rajani, M. R. 2016. "The Expanse of Archaeological Remains at Nalanda: A Study using Remote Sensing and GIS." Archives of Asian Art 66(1): 1-23.

Ray, R. 1994. Buddhist Saints in India: A Study In Buddhist Values and Orientations. New York: Oxford University Press.

Riede, F. 2016. "Anthropology, Weather and Climate Change (Conference report). "The European Archaeologist 49: 24-27.

Robbins, P. 2007. Lawn People: How Grasses, Weeds, and Chemicals Make Us Who We Are. Philadelphia: Temple University Press.

Ruegg, D.S., 1980. "Ahimsa and Vegetarianism in the History of Buddhism." In Buddhist Studies in Honour of Walpola Rahula, edited by S. Balasooriya et al., 234-241. London: Gordon Fraser.

Samsel, A., and S. Seneff, 2013. "Glyphosate's Suppression of Cytochrome P450 Enzymes and Amino Acid Biosynthesis by the Gut Microbiome: Pathways to Modern Diseases." Entropy 15: 1416-1463.

Sanderson, A. 2011, "Śākta Procedures for Weather Control and other Supernatural Effects through Power over Nāgas: Gārudika Passages in the Śākta Jayadrathayāmala." Letter dated 25 Jan 2011, translations added Feb 11, 2015. Retrieved 24 Feb 2015, from

https://www.academia.edu/10689989/\%C5\%9A\%C4\%81kta Procedures for Weather Control and oth er_Supernatural_Effects through_Power_over_N\%C4\%81gas_G\%C4\%81ru\%E1\%B8\%8Dika_Passages_i n the Jayadrathay\%C4\%81mala.

Schlieter, J. 2014. "Endure, Adapt, or Overcome? The Concept of Suffering in Buddhist Bioethics." In Suffering and Bioethics, edited by R. M. Green and N. J. Palpant, 309-336. New York: Oxford University Press.

Schopen, G., 2006. "The Buddhist 'Monastery' and the Indian Garden: Aesthetics, Assimilations, and the Siting of Monastic Establishments." Journal of the American Oriental Society 126 (4): 487-505.

Schopen, G., 1994. "Doing Business for the Lord: Lending on Interest and Written Loan Contracts in the Mūlasarvāstivāda-Vinaya." Journal of the American Oriental Society 114(4): 527-54.

Schmithausen, L. 1997. "The Early Buddhist Tradition and Ecological Ethics." Journal of Buddhist Ethics 4(1): 1-74.

Schumacher, E.F. 1973. Small is Beautiful: Economics as if People Mattered. London: Blonde and Briggs. Sen, S. 2014. "Crossing The Boundaries of The Archaeology of Somapura Mahavihara: Alternative Approaches and Propositions." Pratnatattva 20: 49-79.

Shaw, J. Forthcoming. Archaeologies of Well-being: Environmental Ethics and Buddhist Economics in Ancient India. 
Shaw, J. 2015, "Buddhist and Non-Buddhist Mortuary Traditions in Ancient India: Stūpas, Relics and the Archaeological Landscape." In Death Rituals and Social Order in the Ancient World: Death Shall Have No Dominion, edited by C. Renfrew, M. Boyd, and I. Morley, 382-403. Cambridge: Cambridge University Press.

Shaw, J. 2013a. "Archaeologies of Buddhist Propagation in Ancient India: 'Ritual' and 'practical' models of religious change." World Archaeology 45(1): 83-108.

Shaw, J. 2013b. "Archaeology of Religious Change: Introduction." World Archaeology 45(1): 1-11. Shaw, J. 2013c. "Sanchi as an Archaeological Area." In History of Ancient India, vol. 4, edited by D.K. Chakrabarti and M. Lal, 388-427. New Delhi: Vivekananda International Foundation and Aryan Books.

Shaw, J. 2011. "Monasteries, Monasticism, and Patronage in Ancient India: Mawasa, a Recently Documented Hilltop Buddhist Complex in the Sanchi area of Madhya Pradesh." South Asian Studies 27(2): 111-130.

Shaw, J. 2007. Buddhist Landscapes in Central India: Sanchi Hill and Archaeologies of Religious and Social Change, c. 3rd Century BC to 5th Century AD. London: British Association for South Asian Studies, British Academy; Leftcoast Press.

Shaw, J. 2004. "Nāga Sculptures in Sanchi's Archaeological Landscape: Buddhism, Vaișnavism and Local Agricultural Cults in Central India, first century BCE to fifth century CE." Artibus Asiae LXIV(1): 5-59. Shaw, J. 2000. "Ayodhya's Sacred Landscape: Ritual Memory, Politics and Archaeological 'Fact'." Antiquity 74: 693-700.

Shaw, J., A. Malinar, and J. Schlieter. Forthcoming. "Religion and Nature in Ancient India: Interdisciplinary Perspectives." South Asian Studies.

Shaw, J., J. V. Sutcliffe, L. Lloyd-Smith, J-L. Schwenninger, and M.S. Chauhan, with contributions by E. Harvey and O.P. Misra, 2007. "Ancient Irrigation and Buddhist History in Central India: Optically Stimulated Luminescence and Pollen Sequences from the Sanchi Dams." Asian Perspectives 46(1): 166201.

Shaw, J., and J.V. Sutcliffe, 2005. "Ancient Dams and Buddhist Landscapes in the Sanchi area: New Evidence on Irrigation, Land use and Monasticism in Central India." South Asian Studies 21: 1-24. Shaw, J., and J.V. Sutcliffe, 2003. "Water Management, Patronage Networks and Religious Change: New Evidence from the Sanchi Dam Complex and Counterparts in Gujarat and Sri Lanka." South Asian Studies 19: 73-104.

Shaw, J., and J.V. Sutcliffe 2001. "Ancient Irrigation Works in the Sanchi Area: An Archaeological and Hydrological Investigation." South Asian Studies 17: 55-75.

Sherratt, A. 1999. "Cash-crops Before Cash: Organic Consumables and Trade." In The Prehistory of Food: Appetites for Change, edited by C. Gosden, and J.G. Hatler, 13-34. London: Routledge.

Shimada, A. 2012. "The Use of Garden Imagery in Early Indian Buddhism." In Garden and Landscape practices in Pre-Colonial India: Histories From the Deccan, edited by D. Ali and E. Flatt, 18-38. London: Routledge.

Shiva, V. 1992. The Violence of the Green Revolution: Ecological Degradation and Political Conflict in Punjab. New Delhi: Zed Press.

Simhastha, 2016. "51 Point Universal Message of Simhastha 2016." Conference on 'Living the Right Way' on the occasion of Ujjain's 12-yearly Kumbha Mela Simhastha festival: 12-14 May 2016. https://de.scribd.com/doc/313143904/Simhasth (accessed 1 June 2016).

Skilling, P. 2014. "Every Rise has its Fall: Thoughts on the History of Buddhism in Central India (Part I)." In Buddhist and Jaina Studies: Proceedings of the Conference in Lumbini, February 2013, edited by J. Soni, M. Pahlke, and C. Cuppers, 77-122. Lumbini: Lumbini International Research Institute. 
Smith, B. K. 1990. "Eaters, Food, and Social Hierarchy in Ancient India: A Dietary Guide to a Revolution of Values." Journal of the American Academy of Religion 58(2): 177-205.

Sontheimer, G-D. 1964. "Religious Endowments in India: The Juristic Personality of Hindu Deities."

Zeitschrift für Vergleichende Rechtswissenschaft 69 (1): 45-100.

Steingraber, S. 1997. Living Downstream: An Ecologist Looks at Cancer and the Environment. Boston: Da Capo Press.

Stewart, J. 2014. "Violence and Nonviolence in Buddhist Animal Ethics." Journal of Buddhist Ethics 21: 623655.

Strain, C. 2016. "Engaged Buddhist Practice and Ecological Ethics: Challenges and Reformulations." Worldviews 20: 189-210.

Sutcliffe, J., J. Shaw, and E. Brown, 2011. "Historical Water Resources in South Asia: The Hydrological Background." Hydrological Sciences Journal 56 (5): 775-788.

Swearer, D. 2006. "An Assessment of Buddhist Eco-Philosophy." Harvard Theological Review 99 (2): 123137.

Tewari, R. 2003. "The Origins of Ironworking in India: New Evidence from the Central Ganga Plain and the Eastern Vindhyas." Antiquity 77: 536-544.

Tiyavanich, K. 1997. Forest Recollection: Wandering Monks in Twentieth Century Thailand. Honolulu: University of Hawai'i Press.

Tucker, M.E., W. Jenkins, and J. Grim (eds.), Routledge Handbook of Religion and Ecology. London, New York: Routledge.

Venkayya, V. 1906. "Irrigation in South India in Ancient times." Archaeological Survey of India Annual Review 1903-4: 202-211.

Walters, J. S. 2002. "Mapping Sanchi in a Whole Buddhist World." In Lily De Silva Felicitation Volume, edited by C. Witanachchi, 1-14. Peradeniya: University of Peradeniya.

Wasson, G. G. 1982. "The Last Meal of the Buddha." Journal of the American Oriental Society 104(4): 591603.

Watt, G. 1889-93. A Dictionary of the Economic Products of India. 6 vols. Calcutta and London: W.H. Allen and Co.

Willis, M.D. 2009. The Archaeology of Hindu Ritual: Temples and the Establishment of the Gods . New York: Cambridge University Press.

Wujastyk, D. 2004. "Medicine And Dharma." Journal of Indian Philosophy 32(5-6): 831-842.

Zimmermann, F. 1992. The Jungle and the Aroma of Meats: An Ecological Theme in Hindu Medicine. Berkeley: University of California Press.

Zimmermann, F. 2004. "May Godly Clouds Rain for You! Metaphors of Well-being in Sanskrit." In Du corps humain, au carrefour de plusieurs savoirs en Inde, Mélanges offerts à Arion Rosu par ses collègues et ses amis à l'occasion de son 80ème anniversaire, edited by in E. Ciurtin, 371-384. Studia Asiatica, Volumes IV (2003) et V (2004), Bucarest, Centre d'Histoire des Religions de I'Université de Bucarest \& Paris: De Boccard.

Zimmermann, F. 1980. "Rtu-satmya: The Seasonal Cycle and the Principle of Appropriateness." Social Science and Medicine 14B: 94-106.

Zysk, K. G. 1986. "The Evolution of Anatomical Knowledge in Ancient India, With Special Reference to Cross-Cultural Influences." Journal of the American Oriental Society 106 (4): 687-705.

Zysk, K. 1998. Asceticism and Healing in Ancient India: Medicine in the Buddhist Monastery. New Delhi: Motilal Banarsidass. 